\title{
Arylthienyl-vinyl-benzothiazoles as Efficient Second Harmonic Generators (SHG) for Nonlinear Optics ${ }^{\dagger}$
}

\author{
Rosa M. F. Batista 1,2, Susana P. G. Costa ${ }^{1}$, Michael Belsley ${ }^{2}$ and M. Manuela M. Raposo 1,* \\ 1 Center of Chemistry, University of Minho, Campus de Gualtar, 4710-057 Braga, Portugal; \\ batistarmf@gmail.com (R.M.F.B.); spc@quimica.uminho.pt (S.P.G.C.) \\ 2 Physics Centers of the Universities of Minho and Porto, Campus de Gualtar, 4710-057 Braga, Portugal; \\ belsley@fisica.uminho.pt \\ * Correspondence: mfox@quimica.uminho.pt; Tel.: +351-253-604381 \\ + Presented at the 22nd International Electronic Conference on Synthetic Organic Chemistry, 15 November- \\ 15 December 2018; Available Online: https://sciforum.net/conference/ecsoc-22.
}

Published: 14 November 2018

\begin{abstract}
New push-pull second harmonic generation (SHG) chromophores 2 were synthesized in order to study their linear and nonlinear optical properties. The donor-acceptor $\pi$-conjugated systems 2 were prepared in good to excellent yields by a simple aldol-type condensation of the precursor aldehydes 1 with 6-nitro-2-methyl-1,3-benzothiazole in the presence of $\mathrm{NaOH}$. HyperRayleigh scattering in dioxane solutions was used to evaluate their second-order nonlinear optical properties. The experimental results showed that the optical (linear and nonlinear) properties are influenced by the electron-donor strength of the groups of the $\pi$-conjugated bridge. The vinylbenzothiazole derivative $\mathbf{2} \mathbf{b}$, with methoxyl as the donor group, exhibited the largest first hyperpolarizability $\beta\left(1660 \times 10^{-30} \mathrm{esu}, 40\right.$ times greater than the standard reference $p$ NA molecule $)$ and the highest decomposition temperature $\left(\mathrm{T}_{d}=360^{\circ} \mathrm{C}\right)$. The good balance between nonlinearity and thermal stability makes this compound a promising candidate as second harmonic generator (SHG) for nonlinear optics.
\end{abstract}

Keywords: synthesis; benzothiazole; thiophene; thermal stability; second harmonic generators (SHG)

\section{Introduction}

Organic molecules comprising strong electron donor and acceptor groups connected by a $\pi$ conjugated system (often designated as donor- $\pi$-acceptor or "push-pull" chromophores) are of fundamental importance in materials chemistry due to their numerous applications in modern technology, such as nonlinear optical (NLO) devices, poled polymers, photovoltaic cells, organic light-emitting diodes (OLEDs), semiconductor materials, and optical data storage devices [1-4]. Several push-pull molecules containing benzothiazole as an (auxiliary) electron-withdrawing group have already been reported, and typically exhibit favorable fluorescence, electrochemical, solvatochromic, photochromic, and NLO properties [5-7]. We have reported the synthesis and characterization of the UV-vis, solvatochromic, thermal, and second-order NLO properties of benzothiazole derivatives containing bithienyl [8-9], arylthienyl [10], and thienylpyrrolyl [11-12] heterocyclic $\pi$-spacers in order to evaluate the effect of different $\pi$-excessive donor moieties $/ \pi$ bridges on their optical properties. As an extension of our earlier work and in order to improve the thermal stability and NLO properties of heterocyclic chromophores of the benzothiazole type, we decided to synthesize arylthienyl-benzothiazoles bearing a vinyl spacer between the donor $\pi$ excessive heterocycle (thiophene) and the acceptor $\pi$-deficient benzothiazole moiety. In this work, 
we report the synthesis and characterization of the optical and thermal properties of two vinylbenzothiazole derivatives as second harmonic generators (SHG) for NLO applications.

\section{Materials and Methods}

\subsection{General}

The reaction progress was monitored by thin layer chromatography $(0.25 \mathrm{~mm}$ thick precoated silica plates: Merck Fertigplatten Kieselgel 60 F254), while purification was carried out by silica gel column chromatography (Merck Kieselgel 60; 230-400 mesh). NMR spectra were obtained on a Varian Unity Plus Spectrometer at an operating frequency of $300 \mathrm{MHz}$ for ${ }^{1} \mathrm{H}$ NMR and $75.4 \mathrm{MHz}$ for ${ }^{13} \mathrm{C}$ NMR using the solvent peak as the internal reference. The solvents are indicated in parentheses before the chemical shift values ( $\delta$ relative to TMS and given in ppm). Mps were determined on a Gallenkamp apparatus and are uncorrected. Infrared spectra were recorded on a BOMEM MB 104 spectrophotometer. UV-vis absorption spectra $(200-800 \mathrm{~nm})$ were obtained using a Shimadzu UV/2501PC spectrophotometer. Mass spectrometry analyses were performed at the "C.A.C.T.I.Unidad de Espectrometria de Masas" at the University of Vigo, Spain. Thermogravimetric analysis of samples was carried out using a TGA instrument model Q500 from TA Instruments. 5Phenylthiophene-2-carbaldehyde $\mathbf{1 a}$ and 5-(4-methoxyphenyl)thiophene-2-carbaldehyde $\mathbf{1} \mathbf{b}$ used as precursors for the synthesis of compounds 2 were purchased from Aldrich and Acros and used as received. The synthesis of 6-nitro-2-methyl-1,3-benzothiazole has been reported previously and is commercially available (CAS 2941-63-1). Nevertheless, in our work, it was prepared from the corresponding 2-methyl-1,3-benzothiazole following the literature procedure [13].

\subsection{General Procedure For the Synthesis of Compounds $\mathbf{2}$}

To a solution of 6-nitro-2-methylbenzothiazole $(0.20 \mathrm{mmol})$ and arylthienyl-aldehydes $1(0.20$ $\mathrm{mmol})$ in ethanol $(5 \mathrm{~mL})$, a solution of $\mathrm{NaOH}(0.30 \mathrm{mmol})$ dissolved in a minimum amount of water was added dropwise. The reaction mixture was left stirring at room temperature for 3-5 $\mathrm{h}$ and the resulting precipitate was collected and purified by recrystallization from ethanol.

6-Nitro-2-[(E)-2-(2'-phenylthienyl)vinyl]-1,3-benzothiazole (2a). Orange solid (70\%). Mp: 221.0-222.0 ${ }^{\circ} \mathrm{C}$. UV (1,4-dioxane): $\lambda_{\max } \mathrm{nm}\left(\varepsilon / \mathrm{M}^{-1} \mathrm{~cm}^{-1}\right) 415.0$ (18,165). IR (Nujol) $v$ 3109, 1777 (C=C), 1607, 1566, 1515, $1333,1286,1223,1131,1100,1064,946,919,892,834,758 \mathrm{~cm}^{-1} .{ }^{1} \mathrm{H}$ NMR (DMSO- $\left.d_{6}\right) \delta 7.33$ (d, $1 \mathrm{H}, J$ (trans) $=15.6 \mathrm{~Hz},=\mathrm{CH}), 7.35-7.36\left(\mathrm{~m}, 1 \mathrm{H}, \mathrm{H}-4^{\prime \prime}\right), 7.43-7.47\left(\mathrm{~m}, 2 \mathrm{H}, \mathrm{H}-3^{\prime \prime}\right.$ and H-5"), $7.55(\mathrm{~d}, 1 \mathrm{H}, J=4.0 \mathrm{~Hz}, \mathrm{H}-$ $\left.3^{\prime}\right), 7.59\left(\mathrm{~d}, 1 \mathrm{H}, J=4.0 \mathrm{~Hz}, \mathrm{H}-4^{\prime}\right), 7.71\left(\mathrm{~d}, 2 \mathrm{H}, J=7.2\right.$ and $1.6 \mathrm{~Hz}, \mathrm{H}-2^{\prime \prime}$ and $\left.\mathrm{H}-6^{\prime \prime}\right), 7.98(\mathrm{~d}, 1 \mathrm{H}, J$ (trans) $=16$ $\mathrm{Hz},=\mathrm{CH}), 8.09(\mathrm{~d}, 1 \mathrm{H}, J=8.8 \mathrm{~Hz}, \mathrm{H}-4), 8.30(\mathrm{dd}, 1 \mathrm{H}, J=8.8$ and $2.4 \mathrm{~Hz}, \mathrm{H}-5), 9.07(\mathrm{~d}, 1 \mathrm{H}, J=2.4 \mathrm{~Hz}, \mathrm{H}-$ 7). ${ }^{13} \mathrm{C}$ NMR (DMSO-d6) $\delta 118.64$ (C-7), 119.31 (=CH), 121.47 (C-5), 122.15 (C-4), 124.74 (C-3'), 125.29 (C-2" and C-6"), $128.11\left(\mathrm{C}-4^{\prime \prime}\right), 128.84\left(\mathrm{C}-3^{\prime \prime}\right.$ and C-5"), $132.04(=\mathrm{CH}), 132.32\left(\mathrm{C}-4^{\prime}\right), 132.79\left(\mathrm{C}-1^{\prime \prime}\right), 134.61$ (C-7a), 138.83 (C-5'), 144.02 (C-6), 146.11 (C-2'), 157.08 (C-3a), 171.74 (C-2). MS (FAB) $m / z$ (\%): 365 ([M $\left.+\mathrm{H}]^{+}, 28\right), 307$ (35), 289 (16), 155 (37), 154 (100). HRMS: (FAB) $m / z$ (\%) for $\mathrm{C}_{19} \mathrm{H}_{12} \mathrm{~N}_{2} \mathrm{O}_{2} \mathrm{~S}_{2}$; calcd 365.0418; found 365.0424 .

6-Nitro-2-[(E)-2-(2'-(4"-methoxyphenyl)thienyl)vinyl]-1,3-benzothiazole (2b). Orange solid (80\%). Mp: 205.0-206.0 ${ }^{\circ} \mathrm{C}$. UV (1,4-dioxane): $\lambda_{\max } \mathrm{nm}\left(\varepsilon / \mathrm{M}^{-1} \mathrm{~cm}^{-1}\right) 430.0$ (14,055). IR (Nujol) $v 1671$ (C=C), 1616, $1604,1592,1507,1335,1248,1178,1127,1027,946,833,809,754,720 \mathrm{~cm}^{-1} .{ }^{1} \mathrm{H}$ NMR (DMSO- $\left.d_{6}\right) \delta 3.81$ $\left(\mathrm{s}, 3 \mathrm{H}, \mathrm{OCH}_{3}\right), 7.00\left(\mathrm{~d}, 2 \mathrm{H}, J=6.8\right.$ and $2.0 \mathrm{~Hz}, \mathrm{H}-3^{\prime \prime}$ and $\left.\mathrm{H}-5^{\prime \prime}\right), 7.26\left(\mathrm{~d}, 1 \mathrm{H}, J_{\text {(trans) }}=15.6 \mathrm{~Hz},=\mathrm{CH}\right), 7.42$ $\left(\mathrm{d}, 1 \mathrm{H}, J=4.0 \mathrm{~Hz}, \mathrm{H}-3^{\prime}\right), 7.54\left(\mathrm{~d}, 1 \mathrm{H}, J=4.0 \mathrm{~Hz}, \mathrm{H}-4^{\prime}\right), 7.63\left(\mathrm{dd}, 2 \mathrm{H}, J=6.8\right.$ and $2.0 \mathrm{~Hz}, \mathrm{H}-2^{\prime \prime}$ and H-6"), $7.96\left(\mathrm{~d}, 1 \mathrm{H}, J_{\text {(trans) }}=16 \mathrm{~Hz},=\mathrm{CH}\right), 8.07(\mathrm{~d}, 1 \mathrm{H}, J=9.2 \mathrm{~Hz}, \mathrm{H}-4), 8.28(\mathrm{dd}, 1 \mathrm{H}, J=8.8$ and $2.4 \mathrm{~Hz}, \mathrm{H}-5)$, $9.05(\mathrm{~d}, 1 \mathrm{H}, J=2.4 \mathrm{~Hz}, \mathrm{H}-7) .{ }^{13} \mathrm{C}$ NMR (DMSO- $\left.d_{6}\right) \delta 55.04\left(\mathrm{OCH}_{3}\right), 114.46\left(\mathrm{C}-3 "{ }^{\prime \prime}\right.$ and C-5"), 118.59 (C-7), $118.67(=\mathrm{CH}), 121.45$ (C-5), $122.05(\mathrm{C}-4), 123.53\left(\mathrm{C}-3^{\prime}\right), 125.53\left(\mathrm{C}-1^{\prime \prime}\right), 126.74$ (C-2" and C-6"), 132.21 (=CH), 132.56 (C-4'), 134.55 (C-7a), 137.74 (C-5'), 143.95 (C-3a), 146.42 (C-2'), 157.12 (C-6), 159.47 (C4"), 171.84 (C-2). MS (FAB) m/z (\%): 395 ([M + H] $\left.]^{+}, 37\right), 307$ (41), 289 (19), 155 (32), 154 (100). HRMS: (FAB) $m / z(\%)$ for $\mathrm{C}_{20} \mathrm{H}_{14} \mathrm{~N}_{2} \mathrm{O}_{3} \mathrm{~S}_{2}$; calcd 395.0524; found 395.0536 . 


\subsection{Nonlinear Optical Measurements Using the Hyper-Rayleigh Scattering (HRS) Method [14]}

The hyper-Rayleigh scattering (HRS) technique was used to measure the angle averaged first hyperpolarizability $\beta$ of the molecules studied. The experimental set-up for hyper-Rayleigh measurements employed a q-switched Nd:YAG laser and is similar to the one presented by Clays and Persoons [14-15]. Details of the experimental procedure used have been previously published [11]. We emphasize that particular care was taken to avoid reporting artificially high first hyperpolarizabilities by using a pair of interference filters to estimate and correct for the presence of a possible contamination of the hyper-Rayleigh signal by molecular fluorescence near $532 \mathrm{~nm}$. Further cautions include normalizing the hyper-Rayleigh signal at each pulse using the second harmonic signal from a $1 \mathrm{~mm}$ quartz plate to compensate for fluctuations in the temporal profile of the laser pulses due to longitudinal mode beating and filtering of the solutions, using a $0.2 \mathrm{~mm}$ porosity filter, to avoid spurious signals from suspended impurities. Dioxane was used as a solvent for all measurements. To calibrate our system, a reference solution of $p$-nitroaniline ( $p$ NA) [16-17] dissolved in dioxane at a concentration of $1 \times 10^{-2} \mathrm{~mol} \mathrm{dm}^{-3}$ (external reference method) was used. The hyperpolarizability of $p$ NA dissolved in dioxane is known from EFISH measurements carried out at the same fundamental wavelength [16-17]. All solutions were filtered ( $0.2 \mathrm{~mm}$ porosity) to avoid spurious signals from suspended impurities. The small hyper Rayleigh signal that arises from dioxane was taken into account. Kaatz and Shelton [18] have measured the value of $\beta_{333}$ of $p$ NA in dioxane at $1064 \mathrm{~nm}$ to be $40 \times 10^{-30}$ esu using the so-called Taylor convention for the first hyperpolarizability [19]. This value has been corrected by a factor of 1.88 for the most recent calibration factor of the hyper-Rayleigh scattering signal of $\mathrm{CCl}_{4}$, which was used as a reference [20].

\subsection{Thermogravimetric Analysis of Benzothiazoles 2}

Thermogravimetric analysis of samples was carried out using a TGA instrument model Q500 from TA Instruments, under high purity nitrogen supplied at a constant $50 \mathrm{~mL} \mathrm{~min}^{-1}$ flow rate. All samples were subjected to a $20^{\circ} \mathrm{C} \mathrm{min}-1$ heating rate and were characterized between 25 and $800{ }^{\circ} \mathrm{C}$.

\section{Results and Discussion}

\subsection{Synthesis}

Benzothiazoles 2 with arylthienyl $\pi$-bridges were obtained in good yields $(70-80 \%)$ by the condensation of 6-nitro-2-methyl-1,3-benzothiazole with formyl derivatives 1a-b in ethanol, in the presence of aqueous sodium hydroxide solution, at room temperature for 3-5 h (Scheme 1, Table 1). In our work, the 2-methyl-1,3-benzothiazole precursor was functionalized with a nitro withdrawing group at position 6, which promoted great advantages: (i) increase the acidity of methyl protons at position 2, which afford minor reaction times and better yields; and (ii) the reaction products obtained were vinyl products in the absence of aldol intermediates, without heating the reaction mixture. 6Nitro-2-methyl-1,3-benzothiazole has been reported previously and is commercially available. It was easily prepared in $84 \%$ yield by the nitration of 2-methyl-1,3-benzothiazole using a mixture of nitric acid/sulfuric acid (3:1) as nitration agents [13] in sulfuric acid at $2-3{ }^{\circ} \mathrm{C}$ for $30 \mathrm{~min}$.

The ${ }^{1} \mathrm{H}$ NMR and ${ }^{13} \mathrm{C}$ NMR data of vinyl-benzothiazole derivatives 2 were consistent with the designed structures. In the ${ }^{1} \mathrm{H}$ NMR spectra, signals at about 7.26-7.33 ppm and 7.96-7.98 ppm were detected. All signals appeared as duplets, with a $J(\mathrm{H}, \mathrm{H})$ coupling constants range of $16.0 \mathrm{~Hz}$, and were attributed to the vinylic protons $(\mathrm{CH}=\mathrm{CH})$. These coupling constants clearly confirm the selective formation of trans-configurated double bonds. A strong correlation could be observed between the $\pi$-bridge donor properties and the chemical shift of the vinylic protons in compounds 2 (Table 1). In fact, the increase of the donor ability of the attached group at the donor end of the $\pi$ conjugated bridge (the comparison between compound $\mathbf{2} \mathbf{a}, \mathrm{R}=\mathrm{H}, \delta=7.33 \mathrm{ppm}$ and compound $\mathbf{2} \mathbf{b}$, $\mathrm{R}=\mathrm{OMe}, \delta=7.26 \mathrm{ppm}$ ) decreased the chemical shift of the vinylic protons. In the IR spectra of compounds 2 , the vinylic $=\mathrm{CH}$ was identified as a sharp band within the spectral region of 1671-1777 $\mathrm{cm}^{-1}$. 


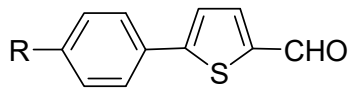

1a $\mathrm{R}=\mathrm{H}$ 1b $\mathrm{R}=\mathrm{OMe}$

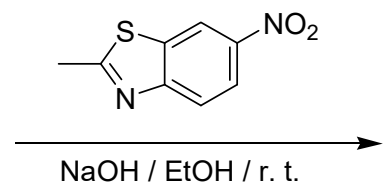

$\mathrm{NaOH} / \mathrm{EtOH} /$ r. t

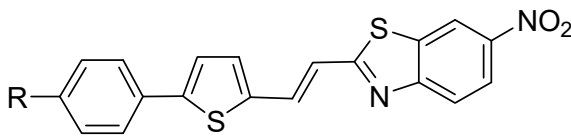

2a $\mathrm{R}=\mathrm{H}$

2b $\mathrm{R}=\mathrm{OMe}$

Scheme 1. Synthesis of arylthienyl-vinyl-benzothiazoles 2.

Table 1. Yields, IR, UV-visible absorption, and ${ }^{1} \mathrm{H}$ NMR data of arylthienyl-vinyl-benzothiazoles 2.

\begin{tabular}{|c|c|c|c|c|c|c|}
\hline \multirow{2}{*}{ Benzothiazole } & \multirow{2}{*}{$\mathbf{R}$} & \multirow{2}{*}{$\begin{array}{c}\text { Yield } \\
(\%)\end{array}$} & \multirow{2}{*}{$\begin{array}{c}\operatorname{IR~} v \\
\left(\mathrm{~cm}^{-1}\right)^{a}\end{array}$} & \multirow{2}{*}{$\begin{array}{c}\delta_{\mathrm{H}} \\
(\mathrm{ppm}) \mathrm{b}\end{array}$} & \multicolumn{2}{|c|}{ UV-Vis } \\
\hline & & & & & $\lambda_{\max }(\mathbf{n m})^{c}$ & $\varepsilon\left(\mathrm{M}^{-1} \mathrm{~cm}^{-1}\right)$ \\
\hline $2 a$ & $\mathrm{H}$ & 70 & 1777 & $7.33 ; 7.98$ & 415 & 18,165 \\
\hline $2 b$ & $\mathrm{OMe}$ & 80 & 1671 & $7.26 ; 7.96$ & 430 & 14,055 \\
\hline
\end{tabular}

a For the $\mathrm{CH}=\mathrm{CH}$ stretching band for compounds 2 (recorded in Nujol). ${ }^{\mathrm{b}}$ For the $\mathrm{CH}=\mathrm{CH}$ proton of

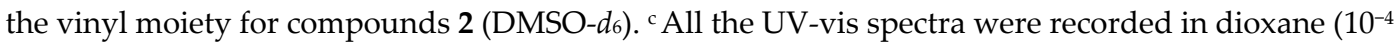
M solution).

\subsection{Photophysical Study of Benzothiazoles 2}

The absorption and emission spectra of arylthienyl-vinyl-benzothiazoles 2 were measured in dioxane ( $\left(10^{-4} \mathrm{M}\right.$ solution) (Tables 1 and 2, Figure 1). The absorption spectra of benzothiazoles 2 showed an intense lowest energy charge-transfer band with high extinction coefficients in the UVvisible region. The position of this band was influenced by the electronic nature of the donor ability of the attached group at the donor end of the $\pi$-conjugated bridge. This can be seen comparing the absorption data for compounds $\mathbf{2 b}\left(\lambda_{\max }=430 \mathrm{~nm}\right)$ and $\mathbf{2 a}\left(\lambda_{\max }=415 \mathrm{~nm}\right)$, in which the replacement of the proton by a stronger donor group as methoxyl induced a bathochromic shift. The same behavior was observed in the emission spectra, with a bathochromic shift at about $30 \mathrm{~nm}$ for compound $\mathbf{2 b}$ in comparison to the unsubstituted 2a. Large Stokes' shifts were observed for chromophores 2, as a consequence of intramolecular charge transfer from the donor to the acceptor moieties after excitation by light. The large Stokes' shift is indicative of a large difference in the spatial arrangement of the chromophore in the absorbing and emitting states, with a consequent increase in the dipole moment and orientational polarizability [21-22].

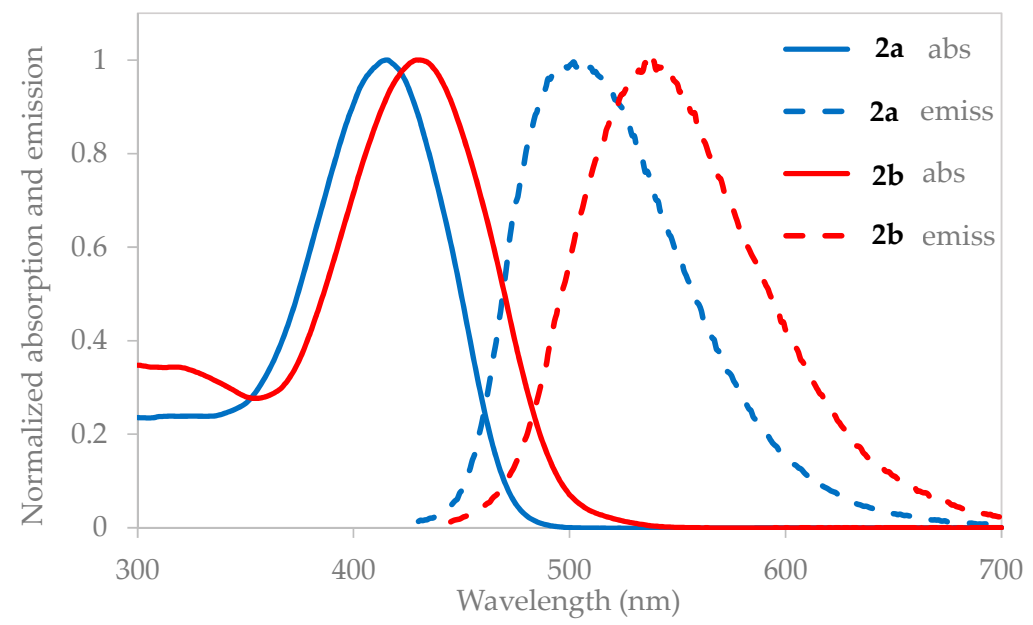

Figure 1. Normalized UV-vis absorption and emission spectra of compounds $\mathbf{2} \mathbf{a}$ and $\mathbf{2} \mathbf{b}$ in dioxane at $\mathrm{T}=298 \mathrm{~K}\left(\mathbf{2} \mathbf{a}, \lambda_{\mathrm{exc}}=415 \mathrm{~nm} ; \mathbf{2 b}, \lambda_{\mathrm{exc}}=430 \mathrm{~nm}\right)$ (absorption, full line; emission, dashed line). 
Table 2. UV-vis and emission data, $\beta$ and $\beta_{0}$ values and $T_{d}$ data for arylthienyl-vinyl-benzothiazoles 2 a.

\begin{tabular}{|c|c|c|c|c|c|c|c|}
\hline \multirow[b]{2}{*}{ Benzothiazole } & \multirow[b]{2}{*}{$\mathbf{R}$} & \multirow{2}{*}{$\begin{array}{c}\text { UV-Vis } \\
\lambda_{\max } \\
(\mathbf{n m})^{\mathrm{a}}\end{array}$} & \multicolumn{2}{|c|}{ Emission } & \multirow{2}{*}{$\begin{array}{l}\beta / 10^{-30} \\
\text { (esu) b }^{b}\end{array}$} & \multirow{2}{*}{$\begin{array}{c}\beta_{0} / 10^{-30} \\
(\text { esu) }\end{array}$} & \multirow{2}{*}{$\begin{array}{c}\mathrm{T}_{d} \\
\left({ }^{\circ} \mathrm{C}\right)\end{array}$} \\
\hline & & & $\begin{array}{c}\lambda_{\mathrm{em}} \\
(\mathrm{nm})\end{array}$ & $\begin{array}{c}\text { Stokes' Shift } \\
\left(\mathrm{cm}^{-1}\right)\end{array}$ & & & \\
\hline $2 a$ & $\mathrm{H}$ & 415 & 506 & 4333 & 273 & 91 & 356 \\
\hline $2 b$ & $\mathrm{OMe}$ & 430 & 537 & 4633 & 1660 & 482 & 360 \\
\hline$p \mathrm{NA}$ & $=$ & 352 & - & - & 40 [18-19] & 20 & ${ }_{-1}$ \\
\hline
\end{tabular}

a Experimental hyperpolarizabilities and spectroscopic data measured in dioxane solutions. ${ }^{\mathrm{b}}$ All the compounds are transparent at the $1064 \mathrm{~nm}$ fundamental wavelength. Values are reported in the $\mathrm{T}$ convention assuming that a single longitudinal element dominates the hyperpolarizabilty tensor. Estimated uncertainties are $10 \%$ of the reported values. ${ }^{c}$ Data corrected for resonance enhancement at $532 \mathrm{~nm}$ using the two-level model with $\beta_{0}=\beta\left[1-\left(\lambda_{\max } / 1064\right)^{2}\right]\left[1-\left(\lambda_{\max } / 532\right)^{2}\right]$; damping factors not included $1064 \mathrm{~nm}[23,24,25,26] .{ }^{d}$ Decomposition temperature $\left(\mathrm{T}_{d}\right)$ measured at a heating rate of 20 ${ }^{\circ} \mathrm{C} \mathrm{min}^{-1}$ under a nitrogen atmosphere, obtained by TGA.

\subsection{Non-Linear Optical Properties and Thermal Stability of Benzothiazoles 2}

We have used the hyper-Rayleigh scattering (HRS) method [14-15] to measure the first hyperpolarizability $\beta$ of benzothiazoles 2 using the $1064 \mathrm{~nm}$ fundamental wavelength of a Q-switched $\mathrm{Nd}$ :YAG laser. Dioxane was used as the solvent, and the $\beta$ values were measured against a reference solution of $p$-nitroaniline (pNA) [16-17] in order to obtain quantitative values, while care was taken to properly account for possible fluorescence of the chromophores. The static hyperpolarisability $\beta_{0}$ values were calculated using the simple two-level model neglecting damping, as proposed by Oudar and Chemla [23-26]. They are therefore only indicative and should be treated with caution (Table 2).

From Table 2, it is observed that the increase of the electron donor strength of the group at the donor end of the arylthienyl $\pi$-conjugated bridge, resulted in both red-shifted absorption maxima and an enhanced $\beta$ value for benzothiazole $2 \mathrm{~b}$ ( $\mathrm{R}=\mathrm{OMe}, \lambda_{\max }=430.0 \mathrm{~nm}, \beta=1660 \times 10^{-30} \mathrm{esu}$ ), compared to derivative $2 \mathrm{a}\left(\mathrm{R}=\mathrm{H}, \lambda_{\max }=415.0 \mathrm{~nm}, \beta=273 \times 10^{-30} \mathrm{esu}\right)$. In general, the values of the molecular hyperpolarizability $\beta$ for benzothiazoles 2 were 7-40 times greater than that of $p \mathrm{NA}$, whereas the $\beta_{0}$ values were 4-24 times higher than that of $p$ NA, respectively. These NLO-phores 2 were specially designed to obtain exceptionally large $\beta$ values. The introduction of a nitro withdrawing group (acting as acceptor part) bound to the benzothiazole auxiliary acceptor moiety promoted an improvement in the acceptor ability and, consequently, enhanced the charge transfer properties.

The thermal stability of chromophores $\mathbf{2}$ was estimated by thermogravimetric analysis (Table 2). As may be observed, the thermogravimetric curves exhibited only one-step weight loss processes with high decomposition temperatures, measured at a heating rate of $20^{\circ} \mathrm{C} \mathrm{min}-1$ under nitrogen. The most stable compound was benzothiazole $\mathbf{2} \mathbf{b}\left(\mathrm{T}_{d}=360^{\circ} \mathrm{C}\right.$ ) (see Figure 2).

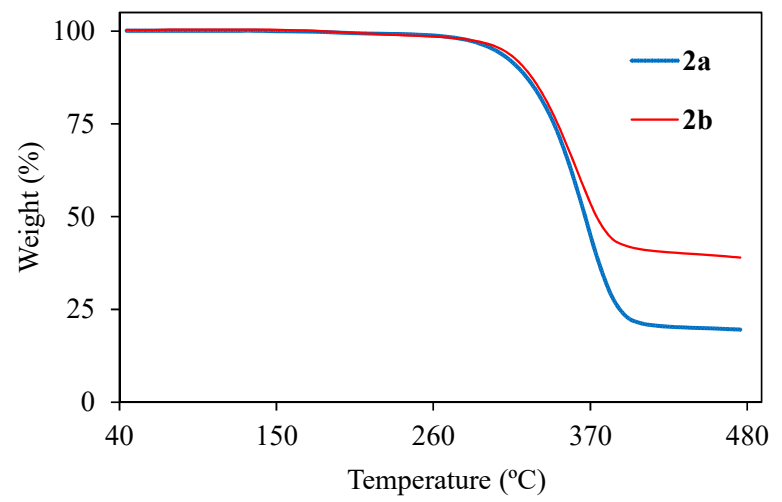

Figure 2. Thermogravimetric curves of compounds $\mathbf{2 a}$ and $\mathbf{2 b}$. Temperature gradient: $20{ }^{\circ} \mathrm{C} \mathrm{min}{ }^{-1}$ under nitrogen. 
The comparison of $\beta$ and $\mathrm{T}_{d}$ values indicates that the nonlinearity and thermal stability are welladjusted for these compounds, particularly for compound $\mathbf{2} \mathbf{b}$, which possesses both the highest $\beta$ value $\left(1660 \times 10^{-30} \mathrm{esu}, 40\right.$ times greater than $\left.p \mathrm{NA}\right)$ and the highest decomposition temperature $\left(\mathrm{T}_{d}=\right.$ $360^{\circ} \mathrm{C}$ ) (Table 2, Figure 2).

\section{Conclusions}

We have synthesized new benzothiazoles 2 in good yields by a simple procedure and their optical properties were evaluated. The donor-acceptor $\pi$-conjugated benzothiazoles 2 functionalized by groups with different electronic characters, have been evaluated and it was proved that the electronic nature of these groups had a significant influence on the SHG properties. In particular, we have shown that chromophore $\mathbf{2} \mathbf{b}$ had a high molecular nonlinearity, as its $\beta$ value was 40 times greater than that of the well-known $p$ NA molecule. Compounds 2 exhibited excellent nonlinearities and high thermal stabilities making them appropriate candidates as push-pull second harmonic generators (SHG) for NLO applications.

Funding: We are grateful to the FUNDAÇÃO PARA A CIÊNCIA E TECNOLOGIA (FCT) for a post-doctoral grant to R.M.F. Batista (SFRH/BPD/79333/2011), FEDER (European Fund for Regional Development)COMPETE-QREN-EU for financial support through the Chemistry Research Centre of the University of Minho (Ref. UID/QUI/00686/2013 and UID/QUI/0686/2016), and the Physics Centers of the Universities of Minho and Porto (Ref. UID/FIS/04650/2013). The NMR spectrometer Bruker Avance III 400 is part of the National NMR Network and was purchased within the framework of the National Program for Scientific Re-equipment, contract REDE/1517/RMN/2005 with funds from POCI 2010 (FEDER) and FCT.

Conflicts of Interest: The authors declare no conflict of interest.

\section{References}

1. Suresh, S.; Ramanand, A.; Jayaraman, D.; Mani, P. Review on theoretical aspect of nonlinear optics. Rev. Adv. Mater. Sci. 2012, 30, 175-183;

2. Beverina, L.; Pagani, G.A. $\pi$-Conjugated zwitterions as paradigm of Donor-Acceptor building blocks in organic-based materials. Acc. Chem. Res. 2014, 47, 319-329;

3. Gu, B.; Zhao, C.; Baev, A.; Yong, K.-T.; Wen, S.; Prasad, P.N. Molecular nonlinear optics: recent advances and applications. Adv. Opt. Photonics 2016, 8, 328-369;

4. Lacroix, P.G.; Malfant, I.; Lepetit, C. Second-order nonlinear optics in coordination chemistry: An open door towards multi-functional materials and molecular switches. Coord. Chem. Rev. 2016, 308 Pt 2, 381-394.

5. Raposo, M.M.M.; Castro, M.C.R.; Belsley, M.; Fonseca, A.M.C. Push pull bithiophene azo-chromophores bearing thiazole and benzothiazole acceptor moieties: synthesis and evaluation of their redox and nonlinear optical properties. Dyes Pigments 2011, 91, 454-465;

6. Raposo, M.M.M.; Castro, M.C.R.; Fonseca, A.M.C.; Schellenberg, P.; Belsley, M. Design, synthesis, and characterization of the electrochemical, nonlinear optical properties, and theoretical studies of novel thienylpyrrole azo dyes bearing benzothiazole acceptor groups. Tetrahedron 2011, 67, 5189-5198;

7. Cigáň, M.; Gáplovský, A.; Sigmundová, I.; Zahradník, P.; Dĕdic, R.; Hromadová, M. Photostability of Dr-A nonlinear optical chromophores containing a benzothiazolium acceptor. J. Phys. Org. Chem. 2011, 24 , $450-459$.

8. Batista, R.M.F.; Costa, S.P.G.; Raposo, M.M.M. Synthesis of new fluorescent 2-(2',2"-bithienyl)-1,3benzothiazoles. Tetrahedron Lett. 2004, 45, 2825-2828;

9. Pina, J.; de Melo, S.S.; Burrows, H.D.; Batista, R.M.F.; Costa, S.P.G.; Raposo, M.M.M. Spectral and photophysical characterization of donor- $\pi$-acceptor arylthienyl- and bithienyl-benzothiazole derivatives in solution and solid state. J. Phys. Chem. A 2007, 111, 8574-8578.

10. Costa, S.P.G.; Batista, R.M.F.; Cardoso, P.; Belsley, M.; Raposo, M.M.M. 2-arylthienyl-substituted 1,3benzothiazoles as new nonlinear optical chromophores. Eur. J. Org. Chem. 2006, 17, 3938-3946.

11. Batista, R.M.F.; Costa, S.P.G.; Malheiro, E.L.; Belsley, M.; Raposo, M.M.M. Synthesis and characterization of new thienylpyrrolyl-benzothiazoles as efficient and thermally stable nonlinear optical chromophores. Tetrahedron 2007, 63, 4258-4265; 
12. Pina, J.; de Melo, J.S.S.; Batista, R.M.F.; Costa, S.P.G.; Raposo, M.M.M. The influence of the relative position of the thiophene and pyrrole rings in donor-acceptor thienylpyrrolyl-benzothiazole derivatives. A photophysical and theoretical investigation. Phys. Chem. Chem. Phys. 2010, 12, 9719-9725.

13. Mizuno, Y.; Adachi, K. Benzothiazoles. Nitration of 2-methyl- and 2-methyl-6-acetylaminobenzothiazoles. YAKUGAKU ZASSHI 1952, 72, 745-747.

14. Clays, K.; Persoons, A. Hyper-Rayleigh scattering in solution. Rev. Sci. Instrum. 1992, 63, 3285-3289;

15. Clays, K.; Persoons, A. Hyper-Rayleigh scattering in Solution. Phys. Rev. Lett. 1991, 66, 2980-2983.

16. Teng, C.C.; Garito, A.F. Dispersion of the nonlinear 2nd-order sptical Susceptibility of organic-systems. Phys. Rev. B 1983, 28, 6766-6773;

17. Stahelin, M.; Burland, D.M.; Rice, J.E. Solvent dependence of the 2nd-order hyperpolarizability in paranitroaniline. Chem. Phys. Lett. 1992, 191, 245-250.

18. Kaatz, P.; Shelton, D.P. Polarized hyper-Rayleigh light scattering measurements of nonlinear optical chromophores. J. Chem. Phys. 1996, 105, 3918-3929.

19. Reis, H. Problems in the comparison of theoretical and experimental hyperpolarizabilities revisited. J. Chem. Phys. 2006, 125, 014506.

20. Pyatt, R.D.; Shelton, D.P. Hyper-Rayleigh scattering from $\mathrm{CH}_{4}, \mathrm{CD}_{4}, \mathrm{CF}_{4}$, and CCl4. J. Chem. Phys. 2001, 114, 9938-9946.

21. Danko, M.; Bures, F.; Kulhanek, J.; Hrdlovic, P. Spectral properties of Y-shaped Donor-Acceptor push-pull imidazole-based fluorophores: comparison between solution and polymer matrices. J Fluoresc. 2012, 22, 1165-1176;

22. Gan, X.P.; Wang, Y.; Ge, X.P.; Li, W.; Zhang, X.Z.; Zhu, W.J.;Zhou, H.P.; Wu, J.Y.; Tian, Y.P. Triphenylamine isophorone derivatives with two photon absorption: photo-physical property, DFT study and bio-imaging. Dyes Pigments 2015, 120, 65-73.

23. Oudar, J.L. Optical nonlinearities of conjugated molecules-stilbene derivatives and highly polar aromaticcompounds. J. Chem. Phys. 1977, 67, 446-457;

24. Oudar, J.L.; Chemla, D.S. Hyperpolarizabilities of nitroanilines and their relations to excited-state dipolemoment. J. Chem. Phys. 1977, 66, 2664-2668;

25. Zyss, J.; Oudar, J.L. Relations between microscopic and macroscopic lowest-order optical nonlinearities of molecular-crystals with one-dimensional or two-dimensional units. Phys. Rev. A 1982, 26, 2028-2048.

26. Oudar, J. L.; Zyss, J. Structural dependence of nonlinear-optical properties of methyl-(2,4-dinitrophenyl)aminopropanoate crystals. Phys. Rev. A 1982, 26, 2016-2027.

(C) 2019 by the authors. Licensee MDPI, Basel, Switzerland. This article is an open access article distributed under the terms and conditions of the Creative Commons Attribution (CC BY) license (http://creativecommons.org/licenses/by/4.0/). 